\title{
Cultivation Restrictions for Genetically Modified Plants
}

\author{
On Variety of Risk Governance in European and International Trade \\ Law
}

Gerd Winter*

Directive (EU) 2015/412 ${ }^{1}$ allows Member States to restrict the cultivation of genetically modified seed or propagating material, although their placing on the market has been authorized. This so-called opt-out is meant to resolve the current Member States' conflict about gene technology by facilitating differences of states concerning cultivation regulations. The concept has at the same time the potential to pioneer a general reorientation of European and even global principles of free trade. Whereas trade restrictions on grounds of health and environmental protection could thus far only be justified on a strict scientific basis, a variety of risk perceptions and evaluations are now made acceptable. The article explores what grounds may justify cultivation restrictions beyond those identified in a concrete environmental risk assessment. Two categories are suggested: general environmental concerns weighing systemic effects and uncertainty, and trans-environmental concerns such as the use-value of genetically modified plants, the avoidance of costs resulting from policies of coexistence with conventional plants, the halting of agricultural industrialisation, and ethical considerations. It is further examined if cultivation restrictions based on such grounds are compatible with the EU rules of free movement of goods and relevant WTO agreements. The pertinent report of a WTO-Panel on genetically modified plants is scrutinized for this purpose and a dissenting interpretation developed.

\section{Preliminary Considerations}

\section{The Trajectory of Regulating Genetic Engineering}

Since its emergence, genetic engineering has triggered significant controversy, which became manifest in society, economy, academia and politics alike. This has not only played out at the domestic level, but also within the EU and on a global scale. In a first phase, compromises were sought for the development of a generally binding framework; in a second phase, when it became obvious that differences were irreconcilable, compromises were sought enabling the coexistence of genetic engineering and conventional or organic agriculture respectively. ${ }^{2}$

The first phase can itself be divided into four stages:
* Professor of Public Law and the Sociology of Law at the University of Bremen and Director of the Research Centre for European Environmental Law. This article is a focussed and improved English version of a report for the German Federal Agency for Nature Protection that was published in Natur und Recht 2015 516-526, 595-606. I am grateful to Josef Falke, Christiane Gerstetter and an anonymous reviewer for helpful comments to earlier drafts.

1 Directive (EU) 2015/412 of 11 March 2015 amending Directive 2001/18/EC as regards the possibility for the Member States to restrict or prohibit the cultivation of genetically modified organisms (GMOs) in their territory, OJ L68, p. 1.

2 See for a similar analysis N. de Sadeleer, Marketing and cultivation of GMOs in the EU. An uncertain balance between centrifugal and centripetal forces, 4/2015 EJRR, pp. 532-558. What would be required in the near future is that an entirely new and broader approach is developed for the regulation of modern biotechnology. This would encompass techniques of highly invasive breeding and of synthetic biology; at the same time, the genetic engineering law-itself in need of revision-would be merged with such an approach. See G. Winter, P. Knoepfel, H.-P. Fricker, The biotechnical utilisation of genetic resources and its regulation. An integrative approach. Bienne (sanu durabilitas) 2014 (http://www.sanudurabilitas.ch/uploads/downloads/5/ Durabilitas_2014_Genetic_resources.pdf 
(1) The controversy over the introduction of genetic engineering in the late 1980s led to national and European legislation that removed genetic engineering from coverage by the more general environmental law on industrial emissions and toxic products, and regulated it separately, especially in the Directives 90/218/EEC and 90/220/EEC and corresponding national laws, such as the German Gentechnikgesetz (GenTG [Genetic Engineering Act]) of 1990.

(2) A new controversy at the end of the 1990s, fanned among other things by the BSE crisis, led to a more restrictive regime with regard to the release and placing on the market of GMOs; it entailed especially a stricter risk assessment and an emphasis on the precautionary principle. The cornerstone of this development was Directive 2001/18/EC ${ }^{3}$.

(3) The controversy found continuation in diverging risk perceptions and policy among Member States (MS). This prompted the adoption of Regulation (EC) $1829 / 2003^{4}$ for genetically modified (GM) food- and feedstuff which transferred authorization to the European level.

(4) The impasse between supportive and rejecting Member States remained both being unable to achieve a qualified majority for or against authorization. Under prevalent competence rules the decision-making powers fell to the Commission,

3 Directive 2001/18/EC of the European Parliament and of the Council of 12 March 2001 on the deliberate release into the environment of genetically modified organisms and repealing Council Directive 90/220/EEC - Commission Declaration, OJ L 106, 17.4.2001, p. 1. Latest consolidated version http://eur-lex.europa .eu/legal-content/EN/TXT/?uri=CELEX:02001L0018-20150402

4 Regulation (EC) No 1829/2003 of the European Parliament and of the Council of 22 September 2003 on genetically modified food and feed (Text with EEA relevance), OJ L 268, 18.10.2003, p. 1. Latest consolidated version http://eur-lex.europa.eu/legal-content/ EN/TXT/?uri=CELEX:02003R1829-20080410 According to the rather dubious - prevailing interpretation food- and feedstuff also encompasses seeds as being "a source material for the production of food" (Art. 2(no. 8) Reg 1829/2003/EC). Cf. Recital 34 and Art. 6(3)(c) of the same Regulation.

5 See Art. 26a Directive 2001/18 which was introduced by Art. 43 Reg 1829/2003.

6 In this text, the term cultivation restriction encompasses the prohibition of cultivation in contrast to the aforementioned Directive, which uses 'restriction' and 'prohibition' separately.

7 Cf. Recital 8 of Directive (EU) 2015/412: "In that context, it appears appropriate to grant Member States, in accordance with the principle of subsidiarity, more flexibility to decide whether or not they wish to cultivate GMOs on their territory without affecting the risk assessment provided in the system of Union authorisations of GMOs, [...]".

8 G. Roth, C. Wittich (eds.) Max Weber, Economy and Society, Berkeley (University of California Press) 1978, p. 1402. which however was reluctant to use them. To the extent that it did use them approvingly, rejecting Member States reacted with cultivation bans, which were based on the powers to introduce additional measures (Art. 95 EC-Treaty, now Art. 114 Treaty on the Functioning of the European Union (TFEU)) or on the safeguard clause of Art. 23 Directive 2001/18/EC.

The second phase brought about a move away from the concept of a fully harmonized seeds regime. Consensus for the market authorisation was now attempted to be reached through enabling divergence of cultivation practices. Two steps can be distinguished:

(5) So-called coexistence measures were accepted. Member States should be able to separate the cultivation, processing and storage of GM and unmodified plants thus allowing both to be handled side by side. ${ }^{5}$

(6) Because such measures are difficult to organize and anyway hardly effective, coexistence policy did not change majorities between Member States. This finally led to the recent more fundamental solution: the introduction through Directive (EU) 2015/412 of an opt-out clause into Directive 2001/18/EC. Member States should retain powers to restrict ${ }^{6}$ the cultivation of GM plants at larger scale, and even country-wide.

In conclusion, the opt-out model is a radical solution to a long-running controversy. Taking recourse to the principle of subsidiarity ${ }^{7}$, it enables a variety of regulatory practices of Member States.

\section{The Uneven Constitutionalisation of Economic and Social/Environmental Interests}

The concept of an opt-out is an innovative move also in the broader context of what can be called the secular economization of societal life of which the ever more technical design of food is a case in point. Opting out allows to position cultural difference in this fundamental trend, a trend that has been grasped by a variety of categories including (sociologically) the formal-rational bureaucracy in economy and state forcing the citizen into a "Gehäuse der Hörigkeit" (shell of bondage) (M. Weber ${ }^{8}$ ), (philosophically) the invasion of the instrumental systems- 
world into the communicative life-world (J. Habermas $^{9}$ ), or (ecologically) the preponderance of the economical over the social and environmental spheres ${ }^{10}$. This development has been legally supported through buttressing economic interests with constitutional protection against governmental regulation, and even granting them subjective rights of stronger build tham those of societal interests. Significant steps in this trajectory were the following:

(1) The fundamental rights to property and profession stipulated in national constitutions, which originally aimed at the liberties of the individual person, were extended to any economic enterprise. ${ }^{11}$ Whether the cobbler in his corner shop or the multinational corporation, all could similarly claim protection of their property and occupational freedom. This meant that any economic regulation that was previously considered to belong to the political sphere was now conceived as an intrusion into basic rights and in consequence became a candidate for review by constitutional oversight. $^{12}$

(2) The free movement of goods was stipulated in the wording of the European Treaties only as an objective principle addressed to the Member States $^{13}$, but was construed as implying subjective rights. ${ }^{14}$ In interplay with the Dassonville-formula, which extended the principle of free trade to any product regulation whether it treated foreign goods differently or not from domestic goods, corporations were entitled to subject any restrictions

9 J. Habermas, The theory of communicative action, Cambridge (Polity Press) 2006, vol. II, chap. VI.2.

10 Cf. G. Winter, A Fundament and Two Pillars. The Concept of Sustainable Development 20 Years after the Brundtland Report, in: H.-C. Bugge and C. Voigt (eds.) Sustainable Development in International and National Law, Groningen (Europa Law Publishing) 2008, pp. 25 - 45

11 Taking Germany as an example the extension of the right to property to business corporations had already been prepared by the Supreme Court of the German Reich (Reichsgericht) and was continued by the Federal Court of Justice (Bundesgerichtshof $\mathrm{BGH}$ ). Cf. H. Rittstieg, Eigentum als Verfassungsproblem, Darmstadt (Wiss. Buchgesellschaft) 1975, pp. 252-271. Concerning the right to profession the Federal Constitutional Court (Bundesverfassungsgericht - BVerfG) detached its protective scope from traditional vocation profiles and included also any "atypical (but permissible) activities freely chosen by individuals" (BVerfGE 7, 377 (397). While in the fine-tuning of the protective intensity the court still somewhat privileged the personal aspect of a vocation, this context has meanwhile been lost almost completely (cf. BVerfGE 68, 193 ff. (206); remnants in BVerfGE 95, 220 et seq. (242) and BVerfGE 99, 367et seq. (389)).

12 For this development and its criticism, which has faded away nowadays, cf. H. Ehmke, Wirtschaft und Verfassung, Karlsruhe (C. F. Müller) 1961, pp. 7 ff., 56 ff. For a late yet somewhat farcical to international trade to review at the European courts. Furthermore, the free movement of goods became the yardstick under primary law for EU secondary legislation-also in the form of a subjective right for corporations. ${ }^{15}$

(3) By dint of case law, the ECJ developed a fundamental right of entrepreneurial freedom, which comes without the individual person as anchor point and positions itself against any European regulation of economic activity. It was codified in the Charter of Fundamental Rights (CFR) as the general freedom to conduct a business (Art. 16) standing apart from the personal freedom to choose an occupation (Art. 15).

(4) International investment treaties and arbitration have given investments of transnational corporations the status of property and thus subjected interventionist state regulation to scrutiny in terms of compensation for indirect expropriation. ${ }^{16}$ International trade law although still being law between states often has its effect in serving trade interests of large enterprises such as producers of asbestos, of cigarettes, of bananas, of genetically modified plants (to name a few at stake in famous dispute settlements). ${ }^{17}$

This constitutionalisation and at the same time subjectivisation of economic interests has not been paralleled by an equal constitutional status of social and even less so of environmental interests. Persons who are not individually and seriously affected have hard-

case of this problematique see BVerfGE 80, $137 \mathrm{ff} .$, where the court declared horse riding in forests as protected by the basic right to developing one's personality, Judge Grimm dissenting pp. 164 et seq.

13 Art. 12 and 13 EECT, now Art. 34 and 35 TFEU.

14 ECJ Case 26/62 (van Gend \& Loos), Slg. 1963, pp. 25 f.; ECJ Case 8/74 (Dassonville) paras. 7/9.

15 ECJ Case 15/83 (Denkavit), para 15. See also fn. 67 below

16 O. Fauchald, Property and environmental protection in investorstate arbitration, in: G. Winter (ed.) Property and environmental protection in Europe, Groningen (Europa Law Publishing) 2016, pp. 77-92.

17 Recent discourses on bringing human rights in into trade disputes (cf E.-U. Petersmann, International economic law in the $21^{\text {st }}$ century, Oxford (Hart Publishing) 2012, chapters IV and VII) are under risk to finally end up with even more strengthening economic property rights. As an example see Petersmann himself, op. cit. p. 469: "By giving private investors directly enforceable rights to challenge governmental investment restrictions [...] international investment law offers private citizens legal and judicial remedies that tend to be more effective in most other areas of international law, including human rights law and international trade law". The statement is true but for the obtuse equating of investors' rights and human rights. 
ly any possibility to take legal action in request for better social or environmental protection. Association actions do have developed instead but only in certain sectors and depending on restrictive procedural preconditions. ${ }^{18}$ Hence, the protection of social and environmental interests largely depends on the political path, i.e. ultimately the willingness of governments to engage themselves.

As a requirement of the constitutionalisation of economic rights such political will must be justified by a public interest and abide by the principle of proportionality. In this way, public interests triggering restrictions on economic freedoms are in a defensive position from the outset. They are pressed in a higher-ranking constitutional and international legal framework and thereby become depoliticized, meaning that the political discretion of the regulator is not anymore solely based on the government's democratic basis but "conceded" by the now responsible courts.

Such concession, or judicial self-restraint, has been more or less generous depending on the national traditions and international contexts of courts. ${ }^{19}$ But in relation to health and environmental protection pol-

18 For an account of subjective rights and locus standi in environmental matters see the contributions in J. H. Jans, R. Macrory, A M. Moreno Molina (eds.) National courts and EU environmental law, Groningen (Europa Law Publishing) 2013, on EU law, and P. Birnie, A. Boyle, C. Redgwell, International law and the environment, Oxford University Press $3^{\text {rd }}$ ed. 2009, pp. 268-315 on international and comparative law.

19 For an elaborate discussion see P. Craig, UK, EU and global administrative law, Cambridge (CUP) 2015, pp. 236-260, 477-487.

20 For the EU see the landmark decision CFI T-13/99 (Pfizer). Cf. Craig, op. cit. pp. 478-487. For the WTO see analysis below, chapter IV..

21 M. Kritikos, Traditional risk analysis and releases of GMOs into the European Union: Space for non-scientific factors? European Law Review 2009, pp. 405 - 432; D. Chalmers, G. Davies, G. Monti, European Union Law, Cambridge (CUP) $2^{\text {nd }}$ ed. 2010, pp. 902-905; P. Lamy, The Emergence of collective preferences in international trade: implications for regulating globalisation. Speech at the Conference on "Collective preferences and global governance: what future for the multilateral trading system", Brussels, 15 September 2004, available at http://europa.eu/rapid/ press-release_SPEECH-04-400_en.htm?locale=en (8.01.2016). See further on the WTO dispute settlement practices infra ch. IV.

22 See further O. Renn, B. Rohrmann (eds.) Cross-cultural risk perceptions. A survey of empirical studies, Dordrecht (Kluwer) 2000.

23 In Germany explanations may be considered that lead back to German romanticism, to holistic conceptions of science and philosophy, to societal learning from the horrific effect of Nazi racial ideology, and others more. Cf. P. Watson, The German genius, New York (HarperCollins) 2010.

24 Art. 26b(1) Directive 2001/18/EC. icy the general mood has been to ask for scientific proof of adverse effects or - where the precautionary approach is accepted - at least scientific indication of risk. ${ }^{20}$

This reliance on science has largely hemmed courts, both European and international, to acknowledge cultural differences in the perception and evaluation of risks. ${ }^{21}$ Cultural traditions affect concerns about the environment and human health, in particular insofar as adverse effects escape scientific proof. ${ }^{22}$ Of course, cultural traditions also induce attitudes beyond the health and environmental realm. For instance, they influence visions about life styles ("do we want meat from cloned pigs?"), agricultural practices ("do we want lifeless villages and dreary landscapes?"), technological progress ("do we want dequalifying high-tech?"), etc. Cultural traditions are rooted in the history of nations and states and are therefore difficult to harmonize. As for the thematic genetically modified plants, cultural traditions allow to explain why GM agriculture is seen rather critically, for instance, in Germany, while attitudes are rather more positive, for instance, in Spain. ${ }^{23}$ The opt-out concept now opens a door for accepting such variety, both in relation to broader environmental and transenvironmental concerns. We will see how the two can be defined and stand the test of court review in terms of the constitutionalised principles of free trade.

\section{The Opt-Out Concept}

Directive (EU) 2015/412 modifies Directive 2001/18/EC by, among others, adding the new Art. $26 \mathrm{~b}$ on opting out. This article sets out the procedure and substance of opt-out measures, their legitimate grounds, and further requirements.

\section{Procedures and the Substance of Measures}

Two possible procedures are introduced:

(1) In an authorization procedure for GM seeds, a Member State can in a statement vis-à-vis the Commission demand to restrict the geographical scope of the authorization. The applicant can adjust the application accordingly, but is not obliged to do so. ${ }^{24}$ 
(2) If the applicant insists in an unrestricted authorization and the latter is granted accordingly, the Member State may itself adopt measures restricting cultivation, after it has given the Commission the opportunity to "make any comments it considers appropriate". ${ }^{25}$

The restriction of cultivation can relate to agricultural practices or entail the entire banning of cultivation of a GMO. It can be limited to specific areas (such as a single nature protection area), categories of areas (such as all Natura 2000 areas) or extend to the entire territory of a state. ${ }^{26}$

\section{Grounds in Summary and Proportionality of Measures}

The cultivation restrictions must be based on grounds determined by Art. 26b (2) Directive 2001/18/EC, including:

a) environmental policy objectives; b) town and country planning; c) land use; d) socioeconomic impacts; e) avoidance of GMO presence in other products; f) agricultural policy objectives; g) public policy.

Since these grounds are only listed as examples, additional grounds can become relevant.

Measures based on these grounds (or, reading grounds as objectives, measures persuing such objectives) need to be proportional. ${ }^{27}$ This means according to EU and Member State jurisprudence that the measure must in view of the objective be appropriate, necessary and proportionate strictu sensu. ${ }^{28}$

When applying this scheme four qualifications should be considered.

First, the core rational of the directive must be brought to effet utile ${ }^{29}$, namely to enable and not to prevent a pluralism of cultivation regulations among the Member States.

Second, both the environmental and the trans-environmental grounds for measures must be acknowledged as legitimate objectives because they are offered by EU legal act.

Third, corresponding to its democratic accountability the regulator has broad discretion to determine what objective to choose, and what measure is appropriate, necessary and proportionate. It has been observed that the ECJ developed differential stan- dards when checking EU legal acts or MS legal acts under EU primary law. Its judicial self-restraint usually is greater in relation to EU action than in relation to MS action. ${ }^{30}$ In the present context we are confronted with a hybrid situation: While it is MS action that is to be checked this action is directed by EU secondary law which intentionally provides the MS with margins of discretion. This means that the standard check would be whether the action was "manifestly inappropriate". ${ }^{31}$ In terms of necessity of means the more demanding and general the policy objective is, the greater the scope of potential alternatives becomes and the more deference of the courts to the choice of the democratically legitimated rulemaker should apply.

A fourth consideration may be added which hardly appears in the CJEU jurisdiction ${ }^{32}$ but more so in pertinent case law of German courts: Proportionality should be checked differently in relation to individual administrative decisions and general legal norms. ${ }^{33}$ In relation to the first any affected individual person must be treated proportionally. However, if general legal norms are concerned, not any individual but the average affected person is taken as reference. According to the BVerfG "the abstract possibility of goal attainment suffices". ${ }^{34}$ In our case of a general regulation, for instance, when the ground for restricting cultivation is to maintain GM-free status of valuable ecosystems, and a ban is generally established for all nature reserves, it is not necessary to go through the individual nature reserves and to con-

25 Art. 26b(4)(c) Directive 2001/18/EC.

26 Art. 26b(3)(cl. 1) Directive 2001/18/EC.

27 Art. 26b(3)(1) Directive 2001/18/EC.

28 See for an authoritative formulation of the doctrine ECJ C-331/88 (Fedesa), para. 14.

29 Effet utile is an interpretation guidance often used by the CJEU to enhance the effectiveness of EU law. See D. Chalmers, G. Davies, G. Monti, European Union Law, Cambridge (CUP) $2^{\text {nd }}$ ed. 2010, p. 1015.

30 Chalmers/Davies/Monti, op. cit. p. 368.

31 ECJ C-331/88 (Fedesa), para. 14.

32 Cf. P. Craig, EU Administrative Law, Oxford (OUP) 2006, chap. 17 and 18.

33 For an example in the ECJ jurisdiction see ECJ C-594/10 (van Laarhoven) para. 33 concerning tax law, where the court held that a flat rate method of calculating taxes is allowed if proportional to its aim

34 BVerfGE 67, 157 (175). In German police law the doctrine was developed that normative acts may be based on an "abstract danger" ("abstrakte Gefahr") while the precondition for individual acts is a "concrete danger" ("konkrete Gefahr"). Cf. C. Gusy, Polizeirecht, Tübingen (Mohr Siebeck) $5^{\text {th }}$ ed. 2003, p. 407. 
sider, whether they would be damaged. Or else, when the ground given is uncertainty about the predicted impact of a specific GMO and a nationwide ban on cultivation is established for this GMO, then it is not necessary to require that the uncertainty is determined for each individual site of cultivation.

\section{The Major Grounds in Detail}

\section{a) Environmental Policy Objectives}

Environmental policy objectives open up a wide field of regulation, which is, however, limited by the proviso that the measures shall not conflict with the environmental risk assessment (ERA) carried out as part of the procedure authorizing the bringing on the market of the GM seed. ${ }^{35}$ The ERA is designed to proceed in 6 steps including an assessment of

1) the hazardous characteristics of the GMO

2) the magnitude of adverse effects

3) the likelihood of their occurrence

4) the risk understood as the combination of magnitude and likelihood

5) the mitigation effects of risk management strategies

6) the resulting overall risk. ${ }^{36}$

In order to determine the latitude available to the Member States, it is advisable to distinguish two intellectual operations in the process of risk regulation, namely the scientific study and appreciation of risks, and the evaluation - or weighing - of risks. In my conception, the study and appreciation of risk is the

35 Art. 26b(3)(2)(2nd subcl.) Directive (EU) 2015/412.

36 Annex II C. to Directive 2001/18 (EC).

37 See for an elaborate concept of the relationship between risk assessment and management the procedural manual of the Codex Alimentarius Commission. Both operations are to be conducted by separate but interacting authorities. The risk manager and not the risk assessor is responsible for drawing conclusions from situations of uncertainty (CAC Procedural Manual, 32rd ed. No. 25, 28 (pp. 112 f.). Available at ftp://ftp.fao.org/codex/Publications/ProcManuals/Manual_23e.pdf 2015 (8.01.2016).

38 See further below sub $\mathrm{bb}$ ).

39 Cf. Art. 114 (3) TFEU; for the WTO agreements see infra ch. IV 1 c) aa).

40 Similarly A. Stirling, On science and precaution in the management of technological risk, EC Joint Research Center, May 1999, pp. 19. ff. (http://ftp.jrc.es/EURdoc/eur19056en.pdf (8.01.2016).

41 Such action would fall under the jurisdiction of the ECJ, see Art. 51(a) ECJ Statute. substance of what is called risk assessment, while the weighing of risk is part of the so-called risk management, which also encompasses the selection and design of appropriate instruments (see the following table 1). ${ }^{37}$ One may distinguish between an "internal" and "external" weighing of risks. ${ }^{38}$ The weighing of risks is also the place for determining the level of protection which in some legal orders is marked as an important step of policy choice. ${ }^{39}$

Table 1: Suggested structure for risk analysis in the EU

\begin{tabular}{|l|l|l|l|}
\hline \multicolumn{2}{|c|}{ risk assessment } & \multicolumn{2}{c|}{ risk management } \\
\hline $\begin{array}{l}\text { study of } \\
\text { risks }\end{array}$ & $\begin{array}{l}\text { appreciation } \\
\text { of risks }\end{array}$ & $\begin{array}{l}\text { weighing of } \\
\text { risks (inter- } \\
\text { nal and ex- } \\
\text { ternal); } \\
\text { choice of } \\
\text { level of pro- } \\
\text { tection }\end{array}$ & $\begin{array}{l}\text { selection } \\
\text { and design } \\
\text { of instru- } \\
\text { ments }\end{array}$ \\
\hline
\end{tabular}

aa) The Scientific Study and Appreciation of Risks In the given context, the study of risks generates scientific statements especially about the characteristics and effects of GMOs. Risk assessment inextricably also includes judgmental appreciation, which still belongs to the realm of science and is open to scientific reasoning. ${ }^{40}$ This is important to note against naive perceptions which assume that science is perfectly value free. Such appreciation includes, for instance: the choice of representative paths of impact to be tested, the interpolation from a path of impact to a similar other one, the assessment of the validity and reliability of a test or of a propagation model, the calculation of a safety factor when conclusions need to be drawn from test animals to protected organisms, the determination of the degree of uncertainty, etc.

If a Member State considers that within an ERA a statement of fact is wrong or that a scientific appreciation is erroneous, it is not allowed to simply deviate, because it would then act contrary to the ERA, which is as said prohibited. Of course, the Member State remains free to take legal action against the allegedly unlawful authorisation. ${ }^{41}$

This is however different, if the ERA concerning a specific GMO does not address certain aspects, especially if certain effects (such as on non-target organisms) are not investigated, although this would be permissible or even necessary according to the 
general rules for ERAs. Member States can scrutinize such effects in a complementary effort; newly gained findings can then be used as basis for their measures. The reason for this is that the ban of conflict according to Art. 26b Directive 2001/18/EC refers to the actually conducted ERA, but not to the general rules of risk assessment as stated in Annex II of Directive 2001/18/EC and the Guidance Paper of the European Food Safety Authority (EFSA) ${ }^{42}$. The respective Member States must conduct an ERA according to established methodology in this case.

\section{bb) Risk Weighing}

One needs to separate scientific statements and appreciation of fact from general evaluations emanating from environmental policy. Such evaluation may take a narrow scientific view and suggest that regulatory measures shall always be based on scientific proof of risks. It may however as well take a more cautious stance concerning the capacity of science, one significant aspect being the treatment of systemic effects and the related unavoidable uncertainty, in other words risks from complex interactions and indirect effects that escape firm scientific evidence. ${ }^{43}$ In this vein risks must be weighed. Of course, conclusions from such weighing may not be purely speculative. They must find ground in and be substantiated by the risk assessment.

As proposed above, the weighing can be "internal" and "external". While the "external" weighing would compare the risks with the expected agro-ecological or other benefits of the GM plant, the "internal" weighing would concentrate on the characteristics of the risks themselves and evaluate them, for instance, in terms of

- a policy of keeping areas free with a view to preserve the self-organization of evolutionary dynamics

- a policy of preserving biodiversity in valuable agro-biotopes

- a cautious take on the problem of uncertainty

- a shift of the onus of proof on the users of gene technology

- a critical view of the choice of comparators with a GMO, such as parental lines

- a particularly cautious stance concerning the likelihood and consequences of a horizontal gene transfer $^{44}$

- an emphasis on the irreversibility of releasing propagating GMOs
- a longer-term perspective on the emergence of adverse effects

- a particular awareness of epigenetic effects ${ }^{45}$

- a more cautious assessment of indirect agro-ecological effects of herbicide-resistant and insecticidal GM plants ${ }^{46}$

- the aim to avoid climate effects caused by the industrialization of agriculture fostered by GMO cultivation

- a focus on systemic objects of protection like biocenoses, ecosystems and biodiversity

It is true that such precautionary and holistic evaluation is partially seen as a task of the ERA in the market authorisation procedure. This poses the question of whether the prohibition of a conflict with the ERA also encompasses such evaluation. Thus, Annex II of the Directive 2001/18/EC laying down the ERA methodology refers under point $\mathrm{D} 2$, inter alia, to subsequent direct and indirect interactions of the GM plant in ecosystems as well as to subsequent direct and indirect effects on agricultural techniques. However, though such more complex effects are frequently touched upon in the practice of ERAs, they commonly rest on weak empirical evidence, for instance, when based on very few studies the conclusion is drawn that "no evidence" of risks exists, or when it is suggested to reduce assumed risks by appropriate

42 EFSA Panel on Genetically Modified Organisms (GMO), Guidance on the environmental risk assessment of genetically modified plants. EFSA Journal 2010;8(11):1879. [111 pp.]. doi:10.2903/j.efsa.2010.1879. Available at http://www.efsa .europa.eu/en/efsajournal/pub/1879.htm.

43 A rich analysis of the possibilities and limitations of the scientific study and assessment of different risks can be found in the Umweltgutachten 1987 des Sachverständigenrats für Umweltfragen (SRU), BT Drs. 11/1568. For the gaps regarding ecotoxicology, see especially No. 3.1.3.2.

44 For the state of the dispute, see Statement of EFSA on the consolidated presentation of opinions on the use of antibiotic resistance genes as marker genes in genetically modified plants, The EFSA Journal (2009) 1108, pp. 1-8.

45 This includes the silencing of genes (gene silencing), position effects in the molecular context of the introduced transgene, und pleiotropic effects, i.e. the simultaneous effect on several characteristics. Cf. Moch et al., Epigenetische Effekte bei transgenen Pflanzen: Auswirkungen auf die Risikobewertung. BfN-Skripten Bd.187, 2006, pp. 20 et seq. http://www.bfn.de/fileadmin/MDB/ documents/service/Skript187_gesamt.pdf (8.01.2016).

46 As with herbicide-resistant seeds that trigger the application of broad spectrum herbicides, which in turn threatens biodiversity (M. S. Heard et al., Weeds in fields with contrasting conventional and genetically modified herbicide-tolerant crops. I. Effects on abundance and diversity. Phil. Trans. R. Soc. Lond. B 358/2003, pp. 1819-1832), or as with insecticidal seeds that release toxins into the soil, cause new resistances, etc. 
cultivation management. ${ }^{47}$ Such remarks transcend what an ERA is meant to do, namely to establish what effects are possible, what their likelihood is, and what degree of uncertainty is involved. To the extent that ERA documents include rough evaluations of indirect effects, the acceptability of risks or even recommended actions, they move into the argumentative realm of risk weighing and the choice of instruments, i.e. the realm of risk management.

The extent to which a risk weighing is apposite depends on the legal provisions applicable in the given case, and especially on the latitude granted to the responsible authority. The wording of Art. $7(1)$ and Art. 19(1) Regulation (EC) 1829/2003 is open ("consider"), refers to "any relevant provisions" of the entire EU law as yardstick and allows "other legitimate factors ${ }^{148}$; hence, discretion is given. In my opinion, risk weighing can be accommodated by this discretionary scope; it can encompass "other legitimate factors", and their anchoring in Art. 26b Directive 2001/18/EC turns them also into "relevant provisions of Community law".

In summary, Art. 26b Directive 2001/18/EC while prohibiting a conflict with the scientific assessment of risk does not exclude different views about the overall risk evaluation. Although the market authorization cannot be questioned, leeway is given with regard to cultivation; here, risk weighing can take place and general environmental policy evaluations can have an impact. Put bluntly, Member States can base their cultivation regulations on those grounds that the Commission is allowed to invoke in its risk management and go beyond a straightforward scientific risk assessment. This applies even to those

47 See, for instance, the argumentation in Scientific Opinion on GM insect resistant and herbicide tolerant maize MON 88017 for cultivation, EFSA Journal 2011;9(11):2428 regarding the effect on non-target organisms and herbicide management.

48 This formulation matches the one used by the Codex Alimentarius Commission, according to which in risk management "decisions should be based on risk assessment, and taking into account, where appropriate, other legitimate factors relevant for the health protection of consumers and for the promotion of fair practices in food trade [...]" (CAC Procedural Manual, 32rd ed.).ftp://ftp.fao.org/codex/Publications/ProcManuals/Manual_23e.pdf (8.01.2016).

49 European Commission, "Framework for the socio-economic analysis of the cultivation of genetically modified crops. First Reference Document, third Draft, 02 July 2014", Available at http://ec.europa.eu/dgs/health_food-safety/dgs_consultations/ docs/ag/sum_20141212 pres 4 en.pdf (8.01.2016); CBD Secretariat, Report of the Ad hoc Technical Expert Group on Socioeconomic Considerations. Annex: Elements of a framework for grounds the Commission has in fact not invoked in a given case.

\section{b) Socio-economic Impacts}

The consideration of socio-economic effects that could result from the cultivation of GMOs allows to reflect on a wide field of consequences. To substantiate them, European and international expert committees compiled some reports, which however do not offer more than general classifications for the steps of analysis and the assessment dimensions. ${ }^{49}$ In general, there is a lack of data on socio-economic effects. Most readily available are studies on profitability of GM and non-GM agriculture as well as on consumer readiness to buy GM products. ${ }^{50} \mathrm{Howev}^{-}$ er, assertions cannot only be drawn from empirically proven facts but also from forecasts based on plausible indicators. ${ }^{51}$ Likewise, the concept of socio-economic impact encompasses not only monetarily measurable effects but also effects that can only be described and assessed qualitatively. ${ }^{52}$ As socio-economic effects one can consider: the costs of coexistence, the lack of benefit, and consumer protection.

\section{aa) Costs of Coexistence}

Recital 15 of Directive (EU) 2015/412 mentions as a socio-economic impact the high costs or the impracticability of coexistence measures. Coexistence costs are to be expected

- for GM-free agriculture insofar as it has to finance studies on whether its products are GMO-free;

- for GM agriculture insofar as it must comply with isolation distances, must keep separate GM and conceptual clarity on socio-economic considerations UN EP/CBD/BS/AHTEG-SEC/1/3. 2014. Available at https://www.cbd .int/doc/meetings/bs/bs-ahteg-sec-01/official/bs-ahteg-sec-01-03 -en.pdf (8.01.2016).

50 See, however, the rather superficial Commission report, European Commission, Report from the Commission to the European Parliament and the Council on socio-economic implications of GMO cultivation on the basis of Member States contributions, as requested by the Conclusions of the Environment Council of December 2008. SANCO/10715/2011 Rev. 5 (POOL/E1/2011/10715/10715R5-EN.doc).http://ec.europa.eu/ food/plant/docs/plant_gmo-socio-economic_considerations-socio _economic_report_gmo_en.pdf (8.01.2016).

51 Similar M. Herdegen in H.-G. Dederer, M. Herdegen, Anbauverbote für gentechnisch veränderte Organismen( „Opt-Out”), Berlin (LIT Verlag) 2015, at fn. 62.

52 The European Commission ignores this in its draft of a Framework for the socio-economic analysis of the cultivation of genetically modified crops (above fn. 49). 
GM-free products and must process them separately;

- for cultivators and producers of non-GM seeds insofar as they must pay attention to varietal purity and introduce the respective protective measures and investigations;

- for cultivators and producers of GM seeds insofar as they must separate from each other their GM and GM-free facilities and activities;

- for those processing and retailing food insofar as they must separate from each other GM-free and GM plant processing and placing on the market;

- for official monitoring, especially when different regulations apply from MS to MS, region to region and site to site;

- from the destruction of contaminated products and from compensating the damages of affected farmers.

Coexistence measures are particularly impracticable in regions of small-scale agriculture, where no sufficient puffer zones can be established. If one were to significantly expand the required puffer zones in response to recent studies into the distances pollen travels ${ }^{53}$, cultivation would also be impeded in other regions.

\section{bb) Lack of Benefit}

Another dimension of the socio-economic impact is the benefit of GM plants that may be considered as such or weighed against environmental risks. In the latter case the socio-economic ground would overlap with the ("external") risk weighing suggested as element of environmental policy. In terms of benefit, it might for instance be doubted whether the use-value of some GM products is better than that of conventional or organic products. ${ }^{54}$

In principle, though, it is constitutionally not permissible that the state decides on use-values and thus determines whether a product is needed; such decisions are the domain of the market. ${ }^{55}$ Nonetheless, this is different, when benefits are considered in order to weigh risks. Thus, for example, it is established that in the authorization of pesticides ${ }^{56}$ risks are weighed against the use-value of a product. $\$ 16(1)$ (no. 3) of the German Genetic Engineering Law (GenTG) also entails such a weighing up. It is likely that riskbenefit analyses are also a, yet implicit, part of the European Commission's practice of authorizing GMOs, when, for instance, an overall risk evaluation concludes that a risk was "acceptable" or "negligible". In such cases the underlying consideration appears to be that the risk is offset by a larger advantage. Hence, when things turn out vice versa, i.e. the risk outweighs the advantage, one could speak of a "needless risk".

The consideration of use-value is, for example, apposite when GM crops are discussed that have an increased content of certain substances, such as vitamin A in a variety of potato. A Member State may decide that this does not increase the use value significantly-consumers might after all also eat carrots - to justify accepting the residual risk of genetic modification. Or it could decide that an increased starch content of potatoes is not desirable, because the scarce agricultural area of potato cultivation was to be reserved for the production of foodstuff. The same would be conceivable with regard to the change of maize for the purpose of better yield when used for energy production.

The benefit can also be assessed in terms of agricultural production method. In this vein, a Member State can follow the argument that a herbicide-resistant plant leads to the application of more broadband herbicides than typically used in conventional agriculture. It could also be argued that an insecticidal property is not necessary in some regions, because the type of pest being addressed did not occur there; the GM seed would therefore be "needless".

\section{cc) Consumer Protection}

Art. 38 CFREU reads: "Union policies shall ensure a high level of consumer protection." The question is whether this article allows to derive that Member States may restrict the cultivation of GMOs, if a majority of their consumers reject GMO cultivation. Art. 38 applies primarily to the institutions of the EU, but must also be observed by the Member States according to Art. 51(1) CFREU. Consumer protection serves, inter alia, consumer choice. The latter is

53 F. Hofmann, M. Otto, W. Wosniok, Maize pollen deposition in relation to distance from the nearest pollen source under common cultivation - results of 10 years of monitoring (2001 to 2010), in: Environmental Sciences Europe 2014, pp. 24 et seq.

54 See also Umweltgutachten 2004 des Sachverständigenrates für Umweltfragen, Baden-Baden (Nomos) 2004, No. 10.2.5.

55 Consistent case-law of the BVerfG since BVerfG 7, 377 ff. (407 f.) and the ECJ, see, for instance, ECJ C-203/96. (Dusseldorp) para. 44.

56 Cf. Art. 4(3) Reg (EC) 1107/2009. 
threatened if no non-GMO products could be consumed anymore due to the unavoidable contamination of the production chain by GMOs. Such reasoning would therefore be legitimate. But it would have to be weighed against the freedom of choice of those consumers who prefer GM products.

\section{c) Agricultural Policy Objectives}

The protection of agricultural ecosystems, the preservation of small-farm agriculture and the promotion of organic agriculture may, inter alia, qualify as agricultural policy objectives. They can partially also be categorized as environmental or socio-economic objectives. This overlap can be explained by the fact that agriculture is dependent on functioning ecosystems, economic livelihood and social embedding. The overlap is acceptable because different grounds can be listed cumulatively. ${ }^{57}$

\section{aa) Protection of Agricultural Ecosystems}

The protection of agricultural ecosystems may, for instance, aim at providing GM-free status of area types in order to preserve biodiversity in valuable agricultural habitats, or at the prevention of indirect agro-ecological effects of herbicide-resistant and insecticidal GM plants.

\section{bb) Agriculture Paysanne}

A Member State could aim to foster a mode of agriculture that detracts from the current trend towards industrialisation. This trend is also fed by gene technology. The question is whether such ground would justify the restriction of GMO cultivation. The leitbild pursued could be what is called "bäuerliche Landwirtschaft" in Germany ${ }^{58}$ (peasant-based agriculture, agriculture paysanne), or "local learning agricultural knowledge, science and technology (AKST)" as suggested as an option by the World Agriculture Report of 2009. ${ }^{59}$ Under European Union law as well as international trade law a protection of products from (as I will call it) agriculture paysanne against competition from industrialised agriculture might be considered to be a protectionist measure. Indeed, if one focuses solely on the profitability of the individual farm, the use of GM seeds may prove to be more efficient than conventional seeds. This effect would become particularly significant in large-scale operations, because genetic engineering allows for further rationalization.

However, the preservation of agriculture paysanne aims at more than just the survival of a (supposedly) inefficient form of economic activity. With it, there is a broader variety of seeds, more diversity of taste and content of the products, more regional markets, more jobs and more social and cultural exchange in villages, which today often degenerate into mere dormitory places. Agriculture paysanne is, hence, also about the social dimension of sustainability. Art. 26b Directive 2001/18 could be the trigger and vehicle to overcome this social blindness of commercial law. ${ }^{60}$
57 Art. 26b(3)(2)(1st sub-cl.) Directive 2001/18/EC.

58 Cf. the description by the Arbeitsgemeinschaft Bäuerliche Landwirtschaft e.V.: "'Bäuerlichkeit'—small-farm life, mindset and economic activity - means a bond with farm, nature and home, responsibility for animals, soil and plants, largely self-directed work, mindset in terms of generations and circuits, work related to the family or other close social relationships. The aim of rural economic activity is of course the best possible income, but always in the context of preserving the work place and farm-and not short-term maximum capital return without regard to the content and location of production. This stands in stark contrast to an agro-industrial orientation." (available at http://www.abl-ev.de/fileadmin/Dokumente/AbL_ev/Agrarpolitik/ 15-03-Beilage_Bauernstimme-kl.pdf (8.01.2016) (author's translation).

59 Local learning AKST is the most promising and workable among four options of agricultural development described in Agriculture at the Crossroads, International Assessment of Agricultural Knowledge, Science and Technology, vol. IV: North America and Europe, 2009 (available at http://www.weltagrarbericht.de/reports/ NAE/NAE_full_report.pdf (8.01.2016), p. 200: "Local learning AKST is regionally focused and proactive in meeting local development and sustainability goals. It is a well coordinated multi- actor system that successfully integrates the different goals at regional and local levels. It successfully contributes to the goals of enhancing livelihoods, equity and social capital and environmental sustainability. Nutrition and human health are improved through knowledge-based sustainable, fresh and safe local diets and a reduction in meat consumption. Balanced regional economic development and stewardship of natural resources are promoted by keeping the added value and employment of input production, processing, transportation and marketing in the region and through investments in quality growth and welfare services. Due to the local orientation, there is little exportation of products or knowledge outside of NAE, but more resources of low-income countries are left untouched by NAE so they can serve other purposes including the provision of food, fiber and fuel for their own consumption. Nevertheless, many technologies developed for NAE could be appropriate for resource-poor rural communities also in low-income countries."

60 Mind that according to Art. 42 sec. 1 TFEU the chapter on competition is only applicable to agricultural production insofar as the European Parliament and the Council so determine respecting the more complex goals of EU agricultural policy. For the WTO see the preamble of the Agreement on Agriculture which prescribes to "have regard to non-trade concerns, including food security and the need to protect the environment." 
One can draw on the Cartagena Protocol ${ }^{61}$ to support such interpretation. Art. 26 of the Protocol entitled "socio-economic considerations" reads:

"(1) The Parties, in reaching a decision on import under this Protocol or under its domestic measures implementing the Protocol, may take into account, consistent with their international obligations, socio-economic considerations arising from the impact of living modified organisms on the conservation and sustainable use of biological diversity, especially with regard to the value of biological diversity to indigenous and local communities.

(2) The Parties are encouraged to cooperate on research and information exchange on any socioeconomic impacts of living modified organisms, especially on indigenous and local communities." (author's emphasis)

There is no indication that the mention of "local communities" only refers to those in developing countries and not also to those in industrialized countries.

\section{cc) Organic Farming}

As additional, specific agricultural policy ground, one can especially add the protection and promotion of organic agriculture. Thus a Member State could designate areas in which predominantly organic agriculture is to develop and be preserved, and prohibit the cultivation of GM crops altogether in such areas. A Member State may also decide that it wants to gradually convert conventional agriculture entirely into organic production, and therefore to close its territory for the cultivation of GM seeds.

\section{d) Ethics and Democracy}

As mentioned, Art. 26b(3) Directive 2001/18/EC lists grounds only as examples and therefore does not rule out other grounds. This may include ethical grounds and those of a democratic public.

\section{aa) Ethical Grounds}

Ethical grounds could be, among others:

- respect for "nature", i.e. what emerges, what lives

- confidence in the learning capacity of evolution's trial and error

- recognition of a plant's genuine character (Eigenart $)^{62}$

- reverence for the Creation.
With its opening clause ("for example"), the directive provides Member States with political latitude. Before the backdrop of the above-mentioned intended pluralisation, this needs to be taken seriously. However, the given leeway needs to conform to primary law, and in particular the principle of the free movement of goods.

Important for those ethical grounds is the judgment of the ECJ in the infringement proceedings against the Republic of Poland, which excluded GM seeds from the catalogue of seed varieties and thus from placing them on the market. Poland had argued $^{63}$ :

"In the present case, the adoption of the contested national provisions was inspired by the Christian and Humanist ethical principles adhered to by the majority of the Polish people.

In that connection, the Republic of Poland goes on to put forward a Christian conception of life which is opposed to the manipulation and transformation of living organisms created by God into material objects which are the subject of intellectual property rights; a Christian and Humanist conception of progress and development which urges respect for creation and a quest for harmony between Man and Nature; and, lastly, Christian and Humanist social principles, the reduction of living organisms to the level of products for purely commercial ends being likely, inter alia, to undermine the foundations of society."

According to Poland's opinion, its ethic-based restriction on GMOs fell outside the scope of application of Directive 2001/18/EC, since this Directive (to be sure: its version before introduction of the opt out clause) only pursues the purpose of health and environmental protection.

The ECJ does not specify whether trade related measures based on ethical grounds are excluded in

61 Cartagena Protocol on Biosafety to the Convention on Biological Diversity, adopted 2000.

62 Under Art. 8 of the Swiss Gene Technology Act, it is a fundamental duty to honour the dignity of living beings: "In animals and plants, modification of the genetic material by gene technology must not impair the dignity of living beings. In particular, impairment is deemed to have occurred if such modification substantially harms species-specific properties, functions or habits, unless this is justified by overriding legitimate interests. In evaluating the harm, the difference between animals and plants must be taken into consideration."

63 ECJ C-165/08 (Commission v Poland) paras. $30 \mathrm{f}$. 
the scope of the Directive, and if so, whether such grounds can be recognized as a justification for trade restrictions in accordance with Art. 28/30 EC Treaty (now Art. 34/36 TFEU). In any case Poland would insofar need to carry the burden of proof for a justifiable ground, but the court found it did not meet this obligation. Poland had raised ethical concerns not as an independent ground but coincided with reasons of health and environmental protection. ${ }^{64}$ It had even not invoked ethical grounds at all when adopting its restriction measures.

If Poland could therefore not argue to have taken a justifiable measure outside Directive 2001/18/EC, the only avenue open would be the application of this very directive, and especially-after a narrowing down of the matter in dispute by the Court-its Art. 22 (free circulation) and Art. 23 (safeguard clause). However, the safeguard clause could be invoked only in the specific situations listed there. These do not include general ethical grounds.

Given the new opt out clause one can conclude from this judgment that the ECJ remains open for the recognition of ethical grounds both under Art. 26b Directive 2001/18 and Art. 34/36 TFEU. However, it establishes almost unrealizable demands on the burden of proof, for ethical reasons cannot be stated equally precise as health or environmental risks. They are inherently general. Nevertheless, in case of a renewed referral of the question of ethical grounds to the ECJ, better substantiation of ethical concerns may persuade the court to approve them.

\section{bb) Democratic Values}

A Member State could try to justify the restricting of cultivation also with reference to the fact that a majority of the population rejects GM foods and wishes domestically produced foods to be GM-free. Such reasoning would in turn have to be tested for its compliance with primary law.

Since Poland had also raised this argument in the aforementioned proceedings, the reply of the ECJ is

64 ECJ C-165/08 paras. $54 \mathrm{f}$.

65 ECJ C-165/08 para. 56.

66 See especially ECJ C-112/00 (Schmidberger), paras. 65 ff., which concerned traffic-obstructing demonstrations against air pollution by heavy goods vehicle traffic on the Brenner motorway.

67 Similar D. H. Kahan, Cultural cognition as a conception of the cultural theory of risk, in: S. Roeser, R. Hillerbrand, P. Sandin, M. Peterson (eds.) Handbook of risk theory, Springer 2012 pp. 725-759. significant. It argued as far as Poland pointed to majority public opinion that a Member State may in accordance with consistent case-law

"not plead difficulties of implementation which emerge at the stage when a Community measure is put into effect, such as difficulties relating to opposition on the part of certain individuals, to justify a failure to comply with obligations and timelimits laid down by Community law (see Case C-121/07 Commission v France [2008] ECR I-oooo, paragraph 72)." ${ }^{65}$

The "obligations" refer to the European fundamental freedoms. In the referenced judgment C-121/07, which dealt with obstructions to the release of GMOs, the ECJ could have referred to the freedom of association under Art. 12 CFREU. In its judgment on Poland, the Court could also have considered the principles of democracy and participation according to Art. 10 and 11 TEU. Other judgments have been much more explicit in pointing to such political fundamental rights as counter-principles to the free movement of goods. ${ }^{66}$

This is not the point to engage with these aspects in more detail. However, it should be noted that a mere majority opinion of consumers determined in surveys does not constitute a legitimate ground for a corresponding government decision. Democracy relies on argument and political controversy. So it depends on what arguments prevail in the procedures provided for participation and decision-making. Accordingly, only substantive grounds are valid grounds such as those discussed above. However, they gain soundness if politically desired by a majority of citizens and consumers. ${ }^{67}$

\section{e) Combination of Grounds}

Grounds can be combined. This means that two selfstanding grounds can be cumulated, and that one ground can be complemented if it would not carry a measure alone. To give an example, for an herbicideresistant rapeseed the following grounds might-either in cumulation or in complement-justify a nationwide cultivation ban:

- environmental policy objectives: the grounds to exclude that the GM property spreads to a wild variety; that more herbicides are applied as previously; that the herbicides used eliminate an unnecessarily wide range of plants; and that plants 
develop resistances to the herbicide tolerated by the crop plant;

- socio-economic impacts: the ground that the advantage of saving farming costs is outweighed by the environmental risk;

- agricultural policy objectives: the ground that the industrialization of agriculture should be slowed down and agriculture paysanne should be promoted; the ground to exclude that seed purity is compromised and that crop variety is diminished;

- other grounds: the respect for a plant-intrinsic "Eigenart" shaped by nature's evolution.

\section{The Compatibility of Measures with the EU principle of free movement of goods}

Art. $26 \mathrm{~b}$ contains the additional proviso that the measures must be in accordance with European Union law. I will concentrate on whether the principle of free movement of goods (Art. 34/36 TFEU) and a principle of coherence of measures (provided it exists at all) may be breached. ${ }^{68}$

\section{Art. 34/36 TFEU}

The ECJ disclaims recourse to Art. 34/36 TFEU if the secondary legal act contains an exhaustive regulation. ${ }^{69}$ We have hence to ask if Art. 26b Directive 2001/18/EC fully harmonises the possibilities and limitations of opt-out measures. The Directive does in fact not aim at harmonisation but at a pluralisa-

68 I leave out the test of compatibility of cultivation restrictions with fundamental rights to enterprise and private property of national constitutions and of the CFREU. Neither do I discuss whether Art. 26b Directive 2001/18/EC itself is compatible with the principle of free movement of goods (cf. in that regard EC) C-15/83 (Denkavit) para. 15). The test is about the same on all of these levels asking whether the public interest is legitimate and the measure proportional. It should be noted that not only the fundamental rights of GM but also that of conventional and organic farming are affected; in sum, this is about balancing multipolar relationships for which the legislator and regulator possesses broad discretion.

69 ECJ C-573/12 - Aaland Vindkraft AB - para. 57: "In that regard, it should be noted that the Court has consistently held that, where a matter has been the subject of exhaustive harmonisation at EU level, any national measure relating thereto must be assessed in the light of the provisions of that harmonising measure and not in the light of primary law."

70 Alternatively one might consider the unspecified grounds enabled by the term "for instance" in Art. 26b Directive 2001/18 as not tion offering different options for measures. It both facilitates and limits options by specifying the allowable grounds and asking for proportionality of measures. The allowable grounds specify the general public interests recognized as legitimating trade restrictions according to Art. 36 TFEU and related court jurisdiction. In a paradoxical formulation, one could speak of a fully harmonized non-harmonization, or, less paradoxical, with the exhaustive structuring of pluralistic solutions. ${ }^{70}$

This means that those Member States that use the opt-out solution operate entirely under the Directive itself. They present no additional grounds that would need to be assessed against the standard of Art. 36 TFEU and other grounds formulated in Community law; they rather utilize grounds that are expressly provided for in Union law. ${ }^{71}$

In an alternative assessment, it may be assumed that the Directive does not exhaust the matter. It must then be asked if cultivation restrictions affect the international trade in goods. Cultivation restrictions are not restrictions on the placing on the market of seeds. GM seeds can still be traded without impediment. The ECJ has, however, regarded restrictions on the use of products to be trade-relevant when they "have the effect of preventing users [...] from using them for the specific and inherent purposes for which they were intended or of greatly restricting their use".72

It is certainly a "specific and inherent purpose" of seeds to be sown. This however would imply that any regulation of cultivation, or, more generally, any use regulation of any product, were subject of a review for the violation of the free movement of goods. The

being harmonized. In that case a partial harmonization would be given. For the possibility of partial harmonization, see ECJ C-402/03 (Skov Aer) paras 22 et seq. It needs to be noted that the entire problematique of Member States introducing additional measures would not have emerged, if the approval of seed had been based on Art. 175 ECT (now Art. 192 TFEU) instead of Art. 95 ECT (now Art. 114 TFEU). This legal foundation is more apposite, since seed is meant to be used stationary, similar to an industrial plant. It would have provided Member States with the latitude of Art. 176 (now Art. 193 TFEU). (I owe this consideration to Ludwig Krämer).

71 On the parallel question of the compatibility of coexistence measures in the realm of Art. 26a Directive 2001/18/EC cf. the statement in ECJ C-36/11 (Pioneer) paras. $70 \mathrm{f}$. that "a prohibition or restriction on the cultivation of those products may be adopted by a Member State in the situations expressly provided for in European Union law. (71) Those exceptions include [...] the coexistence measures adopted under Article 26a of Directive 2001/18."

72 ECJ C-142/05 (Mickelsson and Roos), para. 28. Also ECJ C-110/05 (Commission $\mathrm{v}$ Italy) paras. $56 \mathrm{f}$. 
present article is not the place to discuss in detail such undue extension of the free movement of goods. ${ }^{73}$ After all, the ECJ restrictively examines whether the regulation of use impedes the chances of use greatly, leaving customers to hardly wish to buy this product. It noted in the case of water scooters, for instance, that the actual opportunities to use this device in Sweden were "merely marginal" anymore. ${ }^{74}$ One can assume that the court has a certain threshold of relevance in mind. In the present context, this means that only such a cultivation restriction would enter the scope of Art. 34 TFEU which covers the entire agricultural area of the state territory and which contains a ban and not only certain cultivation requirements.

Assuming that such a nationwide cultivation ban would for a particular GMO be established it would be necessary to consider, whether the trade restriction can be justified. Since the ban would apply to foreign and domestic products alike, the grounds of Art. 36 and other justifiable public interests could be considered. ${ }^{75}$ This endeavour would succeed without great difficulty, given the openness of the concept of Union public interests and the accepted latitude of Member States. General environmental policy evaluations can be based on the provision of precaution under Art. 191(2)(2) TFEU, agricultural grounds on

73 One should note that within the "inherent nature" the ideology of the free movement of goods is reified into a kind of entelechy of the product. Is the inherent nature of a sports car not also hampered, when a state opts for a general speed limit of $120 \mathrm{~km} / \mathrm{h}$ ? Will the manufacturer bring France soon before the ECJ in order to attack the French general speed limit of $120 \mathrm{~km} / \mathrm{h}$ ? One should not object that at the stage of justification certainly many possible grounds could be accepted. Functionally, this is about a further step towards the dominance of the freedoms of business enterprises vis-à-vis societal interests noted above ch. I. 2. In the future, the ECJ will not only decide which items must be purchasable, but what use society has to make of products. Take the example of the sports car: The ECJ would then be able to decide that it is inappropriate and unnecessary to limit traffic speed, when there is little traffic, it is night, there are six lanes, etc. For a similarly critical assessment, see Epiney/Waldmann/Oeschger/Heuck, Die Ausscheidung von gentechnikfreien Gebieten in der Schweiz de lege lata et de lege ferenda, Zürich (Dike Verlag) 2011, p. 27.

74 ECJ C-142/05 para. 25.

75 The ECJ seems to have definitely given up the differentiation of possible grounds with regard to the equal or unequal treatment of foreign and domestic products. Cf. ECJ C-573/12 (Alands Vindcraft $A B)$, para. 76

76 See further the reference to Art. 34/36 TFEU above II. 3. d).

77 Dederer/ Herdegen, op. cit., at fn. 32 and 163.

78 ECJ C-243/01 (Gambelli) para. 67. Also EC) C-316/07 (Stoß) para. 103.

79 In a similar vein EC) C-171/07, 172/07 (Apothekerkammer des Saarlands) para. 42; C-137/09 (Marc Michel Josemans) para. 70. the social objectives of agricultural policy under Art. 39(2) TFEU, socio-economic grounds among others on the consideration clause of Art. 191(3)(3) and (4) TFEU, and ethical grounds among others on the principles of pluralism and tolerance under Art. 2 TFEU. $^{76}$

Next, the proportionality of the measure would need to be justified. However, since this is already required by Art. 26b Directive 2001/18/EC, it has to be already reviewed when this very article is applied. A review under Art. 34 TFEU would only repeat this step and is therefore redundant.

\section{A Requirement of Coherence?}

Dederer and Herdegen in their book on opt-out measures assume a requirement that Member State measures need to be coherent. They argue this requirement would be breached, if for reasons of an agricultural policy aiming at inhibiting the further industrialization of agriculture the cultivation of GM seeds was restricted while conventional agriculture which is also in a process of industrialization is left untouched. $^{77}$

The authors rightly situate the coherence requirement within the principle of proportionality, but ascribe it a fundamental importance it does not deserve. The ECJ so far demands consistency only in the limited sense of excluding the manifest internal inconsistency of specific measures but not in the broad sense of the coherence of entire regulatory policies. In judgments justifying a state monopoly on betting, it argued, for example, that this is not a suitable means to reduce incentives to gamble, if Member States at the same time advertise betting to increase government revenue. ${ }^{78}$ Coherence is therefore indeed to be assessed, when it comes to the question of whether a measure is appropriate in achieving a specific policy objective, but not in the sense of consistency with other policies. ${ }^{79}$ For measures at the EU level, the ECJ in contrast stressed that political institutions are free to initially only intervene partially when pursuing a policy objective and to tackle other cases later, even though they are probably also in need of regulation. In one case, a producer of hydrochlorofluorocarbons claimed that the marketing ban on these substances violated Art. 13or EC Treaty (now Art. 191 TFEU), because it did not cover halons, although halons were even more dangerous. In this 
matter, the ECJ found that the Treaty does not require "the Community legislature, whenever it adopts measures to preserve, protect and improve the environment in order to deal with a specific environmental problem, to adopt at the same time measures relating to the environment as a whole." The Treaty "authorises the adoption of measures relating solely to certain specified aspects of the environment". ${ }^{80}$

If there is no stringent requirement of coherence that would ask for a mandatory equal treatment of GMO-based and conventional agriculture, Dederer and Herdegen have nevertheless highlighted a sore point in the policy of GMO cultivation restrictions. One could capture this in a legally more open form, drawing on the requirement of a concept (Konzeptgebot) suggested by the German BVerwG in comparable cases. The emitters of sulphur dioxide had argued that the best available technology and the corresponding emission limits were disproportionate in geographical areas not exceeding the pollution limits, suggesting that the reduction of their emissions would not contribute to achieving the policy objective. The Court rejected this by arguing that the objective of pollution control was not the small-scale local pollution situation but the management of a national problem of excessive load, which could only be solved with an overall concept that would also encompass such emission sources whose effects are not identifiable individually. ${ }^{81}$

This approach is also applicable to cultivation restrictions, which pursue more general environmental or agricultural policy objectives. What would be required is a "concept" that serves the realization of the chosen general regulatory objective. For example, if a cultivation restriction for GM plants aims at counteracting the industrialization of agriculture, then this has to be embedded in a wider policy of promoting agriculture paysanne and biological agriculture.

\section{The Compatibility of Measures with International Trade Law}

Cultivation restrictions must also comply with international trade law of which the WTO Agreements on Sanitary and Phytosanitary Measures (SPS Agreement), on Technical Barriers to Trade (TBT Agreement) and on Tariffs and Trade (GATT) are pertinent. The obligations under these agreements must be re- spected both by EU and Member State regulators. ${ }^{82}$ I only discuss the sublegal cultivation regulations by Member States, because they ultimately cause the trade restriction, while higher-ranking norms only enable such regulations but do not stipulate them conclusively. When checking compatibility it is important to note the difference between measures based on environmental and/or on trans-environmental grounds.

\section{SPS Agreement}

\section{a) Principles of Interpretation}

When applying the SPS Agreement to regulatory measures, it should be kept in mind that there is a link between the scope and the requirements of the agreement. It would be inconsistent if the scope was extended very far and measures were then subjected to a requirement profile that was created for a narrower scope. Following Annex A (4) of the Agreement and its interpretation by the dispute settlement body $^{83}$, the assessment of the risk that shall be avoided aims at examining scientifically provable causalities. This is appropriate, if the objective of the measure - the environmental endpoint that shall be protected - and the alleged causal factor are precisely determined, such as certain non-target organisms that may be poisoned by the cultivation of a GM plant. Then it makes sense to assess whether the alleged causal relationship between the GM plant and the endpoint is given in fact. Causality becomes blurred, however, if holistic entities like ecosystems shall figure as endpoints and various organisms activating diverse causal chains shall be examined. When the scope of the agreement is construed to apply to measures that regulate such complex interrelations, the regulator is trapped in an impasse because precise causal patterns would have to be asserted and proven. The way out of this trap can only be

\footnotetext{
80 EC) C-284/95 (Safety Hi-Tech Srl) paras. 44, 45.

81 BVerwGE 69, 37 (45 f.).

82 Cf. Art. 216(2) TFEU.

83 European Communities - Measures Concerning Meat and Meat Products, WT/DS26/AB/R, WT/DS48/AB/R 1998, No. 186 f., 200 (in the following cited as EC-Meat Products); European Communities - Measures Affecting the Approval and Marketing of Biotech Products, WT/DS291/R, WT/DS292/R, WT/DS293/R 2006, No. 7.3240 (In the following cited as EC-Biotech Products).
} 
to either exclude measures based on systemic reasons from the scope of the SPS Agreement or to open up the methodology of the risk assessment for systemic cognition.

b) Scope

\section{aa) Legal Basis}

The scope of the Agreement covers sanitary and phytosanitary measures. These are defined in Annex A (1). They comprise measures applied to prevent (a) health risks for animals and plants arising from pests or pathogens; (b) health risks for humans and animals arising from harmful chemicals or pathogens in food or feed; (c) health risks for humans arising from diseases carried by animals or plants or pests; and (d) other damage caused by pests. Measures of this kind are generally held to be legitimate, but subjected to certain conditions that shall prevent protectionist abuse. In our context, where effects of GMOs on the environment are at stake, lit. (a) and (d) are particularly relevant.

\section{bb) The Interpretation of the Panel in EC-Biotech Products}

In the case EC-Biotech Products a Panel was set up on application of the US, Canada and Australia to consider the compatibility with WTO agreements of the authorization proceedings for GM plants of the EC and of trade and use restrictions for GM plants of certain EC Member States. ${ }^{84}$ In its conclusion the Panel did indeed lay the trap: It widened the scope of the Agreement significantly and kept the requirements for measures narrow. In the pending case, this was not at the expense of the charged EC, as the Panel so far only administered justice procedurally and deter-

\footnotetext{
84 EC-Biotech Products, No. 7.3240.

85 EC-Biotech Products, No. 7.3240 and section F (pp. 868 et seq.)

86 Fauna and Flora are mentioned in fn. 5 to Annex A, but the inclusion of the micro level is not intended there. It is rather only concerned with adding wild species to agrarian animals and plants.

87 EC-Biotech Products, No. 7.219.

88 EC-Biotech Products, No. 7.219, 3rd sentence.

89 EC-Biotech Products, No. 7.285 and 7.286

90 International Standard for Phytosanitary Measure No. 11, Pest Risk Analysis for Quarantine Pests Including Analysis of Environmental Risks, FAO, Rome, 2004 (adopted April 2004), Annex 1, p. 34, quoted in EC-Biotech Products, No. 7.235.

91 EC-Biotech Products No. 7.240.
}

mined that the delay of proceedings was an illegal moratorium. By contrast, it used a precise yardstick of a scientific nature against Member States that had restricted the placing on the market or use via the safeguard clause, and largely determined violations. ${ }^{85}$ The scope is extended both in relation to Annex (1) (a) and (d).

\section{- Measures Protecting from Risks to Animals and Plants Caused by Pests (Annex A (1) (a))}

The Panel extends the scope of measures in three directions: the objects of protection, the relevant harmcausing organisms, and the relevant causal processes.

Firstly, the objects of protection - the life and health of animals and plants according to Annex A (1) (a) - are extended by the Panel to any imaginable components and interactions in the physical world. It takes the generalising view that "animals" are part of the "fauna" and extends "fauna" to "micro-fauna"; similarly it takes "plants" to be a part of the "flora" and extends "flora" to "microflora". Its references can be found in footnote 4 to Annex A of the SPS Agreement, which however has a different purpose ${ }^{86}$, and "The Shorter Oxford English Dictionary, L. Brown (ed.) (Oxford University Press, 2002), vol. 1, p. 931".87 In this way, the Panel broadens "textually"88, i.e. without considering meaning and purpose, the scope of the Agreement considerably. Similarly, it also includes biogeochemical components and cycles as well as population dynamics and genetic diversity. ${ }^{89}$ Thus, the Panel blows the rather concrete objects of protection - plants and animals - up to the "environment" in general.

Secondly, the Panel extends the definition of the causal organism, in this case the "pest". It is already difficult to see GM plants as a pest because they are actually designed against pests, such as the insecticidal plant against insects and the herbicide-resistant plant (indirectly) against weeds. Even if one accepts that such GM plants when they harm pests are, so to speak, pests of pests, the question arises which GM plants fall into this category. Although the relevant International Standard for Phytosanitary Measures of the Food and Agriculture Organisation (FAO) defines "pests" as "injurious" ${ }^{10}$, the Panel expands the concept to plants that are just "troublesome or annoying". ${ }^{91}$ This basically includes all GM plants, also, for example, those that do not produce toxins like insecticidal plants, but have certain growth advan- 
tages $^{92}$, such as an acceleration of growth, yield improvement, drought resistance, etc. or grow where they are undesired through pollination. ${ }^{93}$

Thirdly, with regard to the adverse causal processes from pests to animals and plants, the Panel does not concentrate on scientifically provable connections but includes indirect and delayed effects thus extending the scope of the SPS-requirements to measures aiming at controlling those complex causalities. This is done by referring to Annex II Directive 2001/18/EC in which direct, indirect, immediate and delayed effects are mentioned ${ }^{94}$ It is already dubious that the Panel draws on the tested EU provision for interpreting the applicable international standard rather than construing the standard independently of the tested provision. Moreover, when the Panel—very formally_adds that

"there is nothing in Annex A(1)(a) which indicates that potential risks to animal or plant life or health must necessarily be the direct or immediate result of, e.g., the spread of a pest" ${ }^{\text {"95 }}$,

one could counter, in a similarly formal manner, that there are also no arguments for the opposite. What would be required is a view that takes into account the "object and purpose" 96 of what sanitary controls aim at and of when they are abused for protectionist purposes. If a contracting state decides to prohibit the cultivation of GMOs because of those systemic effects, then this does not aim at protecting against specific causal processes but against potential yet hitherto indeterminate processes. In my opinion, such decisions of a general environmental policy nature exceed the horizon of sanitary and phytosanitary measures in the sense of the SPS agreement.

\section{- Measures Preventing Other Damage Caused by}

Pests (Annex A (1) (d)

The Panel also interprets the concept of prevention of "other damages" caused by pests, which according to Annex A No. 1(d) supplements the safety objectives of the letters a) to c) (life and health of humans, animals and plants), in a very broad sense. The Panel takes this to include any damage to property, an economic damage under the condition of coexistence, an impact on biogeochemical cycles and even harm to biodiversity. ${ }^{97}$ It is unclear if the Panel would include also adverse social, ecological, economic, and ethical effects tackled by measures of agricultural, socio-economic or ethical policy. I believe such bound- less expansion would leave the realm of the meaningful, given that the purpose of the SPS Agreement is to protect real animals and plants against pests and diseases. Rightly, the "other damages" should be construed to address only those effects in which the specific harmfulness of pests, here a GMO, has become effective, and where the damage is causally related to health risks to humans, animals or plants. ${ }^{98}$ Economic costs under the condition of coexistence and the social costs of an industrialized agriculture lie outside of this reading, because they do not result out of the potential harmfulness of the pest.

\section{cc) Résumé}

In the proceedings EC-Biotech Products, the EC presented detailed reasons against the mentioned extensions of scope, which it summarized as follows:

"The issues arising out of the existence of GMOs go far beyond the risks envisaged and regulated by the SPS Agreement. A rigorous interpretation of the definitions in Annex A.r of the SPS Agreement unequivocally shows that measures addressing issues such as antibiotic resistance or changes in the ecological balance are not among the measures that the SPS Agreement intends to discipline. Since the European Communities, through its actions, aims at the fulfilment of objectives that go beyond the specific situations that determine the applicability of the SPS Agreement, such Agreement does not provide a sufficient legal framework for the examination of the European Communities' behaviour." ${ }^{199}$

I find this to be a reasonable position. However, it does, as stated, not correspond with the view of the Panel. Unfortunately, the EC did not submit the Panel report to the Appellate Body. Therefore, there is still no conclusive WTO case law on genetic engineer-

\footnotetext{
92 In EC-Biotech Products, they are called "GM plants growing where they are undesired", see No. 7.243-7.247.

93 EC-Biotech Products, No. 7.464.

94 Directive 2001/18/EC Annex II D 2. Cf. EC-Biotech Products, No. 7.285 and 7.286

95 EC-Biotech Products, No. 7.226.

96 Cf. Art. 31(1) Vienna Convention on the Law of Treaties.

97 EC-Biotech Products, No. 7.369-7.373. No. 7.370 even mentions a reputational damage.

98 Similar Dederer in: Herdegen/Dederer, op. cit., fn. 236.

99 EC-Biotech Products, No. 4.355.
} 
ing. In my opinion, it is doubtful whether the Appellate Body would have supported the almost limitless extension of the scope of the SPS Agreement. It is quite possible that GMO-critical EU Member States could have more success in a new dispute settlement proceeding, among others because awareness has grown that the WTO must open itself up for more general environmental policy reasons that justify trade restrictions. ${ }^{100}$

In sum, in my opinion

- the scope of the SPS Agreement only encompasses those grounds that refer to the effects of intrinsically harmful GMOs (i.e., especially insecticide plants) on the health of animals and plants;

- those measures lie outside of the scope that are based on risk weighing, especially those based on fundamental evaluations regarding uncertainties and systemic effects;

- completely outside of the scope are measures aiming at non-environmental objectives.

\section{c) Requirements for SPS Measures}

As far as measures fall under the scope of the SPS Agreement, they must follow certain substantive and methodological requirements. In an alternative approach I will in the following assume the position of

100 Cf. above ch. I. 2.

101 Art. 2.1 SPS Agreement.

102 Australia - Measures Affecting Importation of Salmon, WT/DS18/AB/R 1998, No. 523 (In the following cited as Australia-Salmon).

103 Cf. Art. 3.2 SPS Agreement. Clearly pointed out in AustraliaSalmon, No. 199: "The determination of the appropriate level of protection, a notion defined in paragraph 5 of Annex A, as "the level of protection deemed appropriate by the Member establishing a sanitary ... measure", is a prerogative of the Member concerned and not of a panel or of the Appellate Body." Cf. P. C. Mavroidis, Trade in goods. The GATT and the other WTO agreements regulating trade in goods, Oxford (OUP) 2012, pp. 721, 725 .

104 Art. 5.4 SPS Agreement.

105 Art. 2.2, similar Art. 5.6 SPS Agreement.

106 Australia-Salmon No. 194.

107 See ch. II. 2 above.

108 Art. 5.1 SPS Agreement. Cf. EC-Meat Products, No. 180: "Article 2.2 informs Articles 5.1: the elements that define the basic obligation set out in Article 2.2 impart meaning to Article 5.1."

109 Art. 5.2 SPS Agreement.

110 Art. 2.2 SPS Agreement. It is striking that this requirement is not established for determining the level of protection, except the latter is more stringent than aimed for in international standards (cf. Art. 3.3. SPS Agreement).

111 See for an in-depth analysis Mavroidis, op. cit. pp. 713-723. the Panel so that measures based on general environmental considerations are also included in the analysis. Measures based on trans-environmental grounds are however not further reviewed, since it seems farfetched to assume that they fall under the SPS Agreement.

\section{aa) Legal Basis}

Art. 2.1 SPS Agreement recognizes the contracting states' right to take measures "necessary for the protection of human, animal or plant life or health". ${ }^{01}$ The determination of the level of protection, the choice of measures and the risk assessment basis should be distinguished. It is common ground that the level of protection directs the choice of measures. ${ }^{102}$

\section{- Level of Protection}

In determining the level of protection contracting states are largely free. ${ }^{103}$ Hence, latitude exists that could also legitimize measures resulting from the weighing of risks. In doing so, members have however to "take into account the objective of minimizing negative trade effects." ${ }^{104}$ Therefore, when weighing risks trade effects of measures must be considered.

\section{- Choice of Measures}

The contracting states must ensure that a measure "is applied only to the extent necessary to protect human, animal or plant life or health [...]". ${ }^{105}$ In other words measures must be proportional to their objectives. This is understood as a three pronged test requiring that an alternative measure is reasonably available, achieves the envisaged level of protection and is significantly less restrictive. ${ }^{106}$ As a qualification, I submit that only generalised alternatives in the sense of normative proportionality ${ }^{107}$ are to be tested.

\section{- Risk Assessment}

SPS measures must be based on a risk assessment carried out in accordance with internationally recognized methods. ${ }^{108}$ When assessing risks, the available scientific evidence as well as the relevant ecological and environmental conditions need to be considered. ${ }^{109}$ Measures must be "based on scientific principles". ${ }^{\prime 10}$

This scientific orientation has led the dispute settlement bodies to review risk assessments in detail. ${ }^{111}$ In my opinion, the contracting states howev- 
er possess a margin of judgment. Different reasons support this argument: The protection of health and the environment is not an exception to the fundamental principle of free trade but at least an equivalent principle; ${ }^{112}$ the contracting states are better equipped to resolve scientific questions than the dispute settlement bodies $^{113}$; and the decisions of the WTO dispute settlement bodies possess a lower degree of democratic legitimation than the regulations established by contracting states. ${ }^{114}$

\section{- Precautionary Approach}

In cases where "relevant scientific evidence is insufficient", measures may be "provisionally adopt [ed] [...] on the basis of available pertinent information" including that from the relevant international organizations as well as from sanitary or phytosanitary measures applied by other contracting states. ${ }^{115}$ The interpretation of this clause allows bringing to bear the precautionary approach. That is why the dispute settlement bodies deemed it hitherto unnecessary to decide whether the precautionary principle is already customary international law. ${ }^{116}$

\section{bb) Application to Opt-out Measures}

Applying the above profile of requirements two situations - one for science and one for weighing of risks - should be distinguished.

Cultivation restrictions that are based on a scientific study and appreciation have to follow the recognized risk assessment rules. For instance if a Member State bases its restriction measure on the alleged impact of the GM plant on a specific non-target organism that was not investigated in the ERA it needs to complement the ERA by related scientific study. This should not pose particular difficulties, since the methods of ERA recognized in the EU match international risk assessment standards.

The situation is different when it comes to measures (alternatively assumed that they fall under the SPS Agreement) that are based on general environmental policy evaluations and the weighing of risk. Such evaluation and weighing should be seen as part of determining the level of protection in the sense of Art. 3.2 SPS Agreement and is hence at the discretion of the contracting state. ${ }^{117}$ If a Member State intends, for instance, to avoid the eco-systemic effects of GMO cultivation, it chooses a higher level of protection than in a case in which it merely intends to avoid harm to particular non-target organisms.
Also for measures that shall realise a high level of protection, a risk assessment needs to be conducted. However, one of the strictly scientific kind can in my opinion not be demanded, since, as mentioned earlier, it is based on linear causalities and neglects the complex interconnections within ecosystems. ${ }^{118}$ Rather it must suffice that the risk is substantiated according to the state of the art and that the weighing of risk is motivated.

Contrastingly, the Panel in the EC-Biotech Products case did insist that "a risk assessment must evaluate the likelihood or probability of particular risks". ${ }^{119}$ It held that the assessment of a Member State that an impact was "uncertain", "possible" or "non-conclusive" would not meet this requirement and would thus not justify a restriction. ${ }^{120}$ Since in the given case it found the risk assessment not being adequate it concluded that Art. 5.1 SPS Agreement was violated. It however suggested to test Art. 5.7 SPS Agreement.

A precondition of this provision is that the "relevant scientific evidence is insufficient". The EU Member States that had established a cultivation ban had argued that the required scientific evidence depended upon the chosen level of protection, that was high, and that it could not and need not be proven on a hard scientific basis. ${ }^{121}$ The Panel rejected this claim referring to an opinion of a scientific committee, the EU Scientific Committee on Plants (SCP), that had examined the matter drawing on quite a number of existing studies. The Panel found this to be "sufficient evidence" so that Art. 5.7 SPS Agreement could not be invoked. ${ }^{122}$ It said the information required

\footnotetext{
112 Cf. the preamble to the WTO Agreement.

113 This justification for judicial self-restraint has been suggested by the German Federal Administrative Court, most significantly in BVerwGE 72, 300 (316 f.).

114 Cf. G. Winter, Regimekonflikte im globalisierten Recht: Erscheinungsformen und Lösungen, in: 20/4 GAIA, (2011), pp. 248 - 255.

115 Art. 5.7. SPS Agreement.

116 Cf. EC-Biotech Products, No. 7.89.

117 It should be noted that the SPS Agreement only knows the term risk assessment but not risk management, because the differentiation only appeared after its adoption. Cf. EC-Meat Products, No. 181.

118 See above ch. II. 3. a) bb).

119 See EC-Biotech Products, No. 7.982-7.984 in connection with the review of the Austrian regulation of maize T 25.

120 Ibidem.

121 EC-Biotech Products, No. 7.1129

122 EC-Biotech Products, No. 7.952.
} 
for a risk assessment had to be determined in a purely scientific manner, while the level of protection comes only into play when, as a second step, the acceptability of the risk is assessed. ${ }^{123}$

Thus, in the opinion of the Panel the 'normal' risk assessment under Art. 5.1 required scientific proof which the defendants failed to provide, while the precautionary risk assessment under Art. 5.7 was not applicable because it presupposed uncertainty which the Panel found was not given. The Panel closed its eyes for the possibility of a holistic risk assessment that looks at complex causal interrelationships. It departs from the somewhat naive assumption that risk assessment can be scientifically value-free and definite. ${ }^{124}$ Rather, to what extent scientific rigour is appropriate depends on the chosen level of protection. If the chosen level of protection requires, for instance, the safe exclusion of damage to soil organisms and there is insufficient information available for such a conclusion, it cannot simply be demanded that the probability of damages must nevertheless be determined. A substantiation of risks must suffice in such cases.

My proposal to allow a risk assessment adapted to the level of protection, which possibly only substantiates the risk and justifies its weighing, finds resonance in Art. 5.2 SPS Agreement, according to which a number of other factors can be taken into account, including even the "relevant ecological and environmental conditions". ${ }^{125}$ Some formulations of the Appellate Body point into the same direction, accepting assessments of a qualitative nature ${ }^{126}$ and those of

123 EC-Biotech Products, No. 7.1131 - 7.1134

124 The very definition of risk assessment in Annex A of the SPS Agreement knows both the probability and the potentiality of adveres effects. See EC-Meat Products No. 183-4 and Mavroidis, op. cit. p. 718.

125 Cf. the respective reference in EC-Meat Products, No. 187.

126 European Communities - Measures Prohibiting the Importation and Marketing of Seals Products, WT/DS400/AB/R, WT/DS401/AB/R, No. 5.198.

127 Cf. United States - Continued Suspension of Obligations in the EC - Hormones Dispute, WT/DS320/AB/R 2008, No. 562.

128 EC-Meat Products, No. 187. Also quoted in Appellate Body Report, US - Continued Suspension of Obligations in the EC Hormones Dispute, WT/DS320/AB/R 2008, No. 527.

129 EC-Meat Products, No. 194. Also quoted in United States Continued Suspension of Obligations in the EC - Hormones Dispute, WT/DS320/R 2008, No. 529.

130 United States - Continued Suspension of Obligations in the EC Hormones Dispute, WT/DS320/AB/R 2008, No. 569.

131 Art. 2.5 TBT Agreement. more complex causal relationships ${ }^{127}$. The following often-quoted sentence points to risks as a matter of life praxis:

"It is essential to bear in mind that the risk that is to be evaluated in a risk assessment under Article 5.1 is not only risk ascertainable in a science laboratory operating under strictly controlled conditions, but also risk in human societies as they actually exist, in other words, the actual potential for adverse effects on human health in the real world where people live and work and die."128

The risk assessment must not necessarily come to a "monolithic conclusion", and it can instead of having to follow the scientific mainstream, rather be based on "a divergent opinion from a qualified and respected source". ${ }^{129}$

The opening up of the risk assessment becomes particularly obvious in the following statement:

"Although the definition of a risk assessment does not require WTO Members to establish a minimum magnitude of risk, it is nevertheless difficult to understand the concept of risk as being devoid of any indication of potentiality. A risk assessment is intended to identify adverse effects and evaluate the possibility that such adverse effects might arise. This distinguishes an ascertainable risk from theoretical uncertainty. However, the assessment of risk need not be expressed in numerical terms or as a minimum quantification of the level of risk." ${ }^{130}$

According to this, it is not required to quantify the level of damage and likelihood of occurrence. Required are indications for risks, while a mere theoretical uncertainty is not apposite.

Should there be a new dispute settlement proceeding on GM plants, the odds are therefore not all bad that the competent bodies come to an extended understanding of risk assessment.

\section{Agreement on Technical Barriers to Trade (TBT Agreement)}

As far as the measures fall within the scope of the SPS Agreement and meet its requirements, they are not to be assessed against the TBT Agreement also, because the SPS Agreement has priority. ${ }^{131}$ As explained, this does not include measures that aim at 
general environmental policy objectives or at transenvironmental policy reasons; it needs therefore to be assessed whether such measures fall within the scope of the TBT Agreement. The TBT Agreement differs from the GATT with regard to the question of whether only measures that treat foreign and domestic products differently (so-called discriminatory measures) are in need of justification or also measures that do not treat them differently (so-called nondiscriminatory measures). The TBT Agreement (as well as the SPS Agreement) covers both categories and the GATT only discriminatory measures. ${ }^{132}$ This means that the GATT only aims at preventing protectionist discrimination, while the TBT Agreement claims to discipline the general trade policies of its Members.

Decisive for the scope of the TBT Agreement are its Art. 2.1 and 2.2 the first paragraph prohibiting discriminatory measures and the second both discriminatory and non-discriminatory ones. In any case the measure must be a technical regulation which is defined as a

"Document which lays down product characteristics or their related processes and production methods, including the applicable administrative provisions, with which compliance is mandatory [...]."133

Cultivation restrictions refer to the characteristic of seeds, namely-positively - to its feature as genetically modified or-negatively-as genetically unmodified.

It is questionable, however, whether a document "lays down" this feature. ${ }^{134}$ An abstract definition of characteristics, such as in the form of "it is hereby determined that a seed is genetically modified" would be meaningless. Feature descriptions always occur in a particular context of action. This is meant by the phrase in Annex I "For the purpose of this Agreement, however, the following definitions shall apply". As the Appellate Body emphasizes, "a determination of whether a measure constitutes a technical regulation 'must be made in the light of the characteristics of the measure at issue and the circumstances of the case'". 135

The purpose of the agreement is the liberalization of the trade in products. For this trade, rules and mandatory provisions could be imagined, which state that products with the characteristic "genetically modified" cannot at all or can only under certain conditions be placed on the market. Cultivation restrictions or bans do just not prescribe this. They refer to cultivation. The producer remains free to place the cultivation-restricted products on the market.

One might consider whether the cultivation-related technical regulation affects trade indirectly, because sales opportunities are reduced. But this implies a significant extension of the scope of the TBT Agreement, for which the dispute settlement bodies were hardly legitimated. They would then embark on a similar move to the one pursued by the ECJ in its judgments Mickelsson and Commission v Italy. ${ }^{136}$ At the European level, this is already doubtful but, given the degree of integration within the EU, may be acceptable, if appropriately designed. In the global dimension of the TBT Agreement, this would in my opinion constitute an action taken ultra vires.

As a result, it should be noted that the TBT Agreement is not applicable to cultivation restrictions.

\section{General Agreement on Tariffs and Trade (GATT)}

What remains then is an assessment with regard to Art. III.4 GATT which reads:

"The products of the territory of any contracting party imported into the territory of any other contracting party shall be accorded treatment no less favourable than that accorded to like products of national origin in respect of all laws, regulations and requirements affecting their internal sale, offering for sale, purchase, transportation, distribution or use."

This provision is explicitly also applicable to the regulation of product use, hence also to cultivation restrictions. However, it is presupposed that these regulations must treat foreign products less favourable than like domestic products. Both de iure and de facto differential treatment is considered to breach Art.

\footnotetext{
132 This is not the place to discuss, whether this corresponds to the original intention of the Agreements.

133 Annex 1(1) TBT Agreement.

134 The term "mandatory" is not significant here, since it points to the difference to international standards.

135 EC - Measures Prohibiting the Importation and Marketing of Seal Products, WT/DS400/AB/R no. 5.60.

136 Cf. Above ch. III. 1.
} 
III.4 GATT. However, "there must be in every case a genuine relationship between the measure at issue and its adverse impact on competitive opportunities for imported versus like domestic products to support a finding that imported products are treated less favourably."137 This is not the case here, because all GM plants are subject to precisely the same cultivation restrictions. ${ }^{138}$

In the alternative, it may be assumed to extend the scope of Art. III.4 GATT to cases where foreign products hold - and loose - more market share than domestic ones, as it may be in our case with foreign in relation to domestic GM seed. Then a justification under Art. XX GATT of the differential effects of measures is to be considered. Art. XX (g) GATT ("relating to the conservation of exhaustible genetic resources") could be invoked but the term "exhaustible natural resources" even if broadly understood ${ }^{139}$ can hardly be extended to include systemic interrelations of nature. Measures reflecting general environmental concerns and risk weighing could rather be based on Art. XX (b) ("necessary to protect human, animal or plant life or health") if the term "animal or plant life or health" were broadly interpreted like the Panel in ECBiotech Products did concerning the same terms in Annex A to the SPS Agreement. ${ }^{140}$ I objected against this broad reading so that it might appear contradic-

137 US - Measures Affecting the Production and Sale of Clove Cigarettes, WT/DS406/AB/R, No. 201. EC - Measures Affecting Asbestos and Products Containing Asbestos, WT/DS135/AB/R. 2001, No. 100. Dominican Republic - Measures Affecting the Importation and Internal Sale of Cigarettes, WT/DS302/AB/R, at IV 8.

138 A case of discrimination could be assumed, if one did not compare genetically modified seeds from abroad and home, but genetically modified seeds from abroad with domestic conventional seeds. The former would be limited in regard to cultivation, the latter not. For such a comparison, both product groups would have to be "like" products. This is not the case, because both products vary in their physical properties as well as in the perception and in the behaviour of consumers.

139 See for such extension covering renewable resources US Import Prohibition of Certain Shrimp and Shrimp Products, WT/DS58/AB/R. 1998, No. 131.

140 See above ch. IV 1 b).

141 Cf. the parallel development concerning Art. 36 TFEU the justifiable grounds of which have been flanked by additional grounds in case of non-discriminatory measures. See above fn. 74 .

142 Above ch. II 3 d)

143 EC - Measures Prohibiting the Importation and Marketing of Seal Products, no. 5.199, quoting the Panel in US - Gambling, no. 6.465 , that "the term 'public morals' denotes 'standards of right and wrong conduct maintained by or on behalf of a community or nation". For a support of this understanding see Mavroidis, op. cit. pp. 332-334

144 See further on this problem Mavroidis, op. cit. pp. 326-337. tory that I defend the same in the context of Art. XX GATT. But the difference can be explained. Concerning the SPS Agreement the term disciplines the scope of application of the agreement which should be narrow in order to cope with the narrow concept of risk assessment. Concerning Art. XX GATT the term opens up grounds for justifying trade restrictions and should be broadly understood as a corollary to an assumed extension of the scope of application of Art. III.4 GATT. ${ }^{141}$

Concerning the trans-environmental grounds it appears that the ethical concerns about cultivation of GMOs ${ }^{142}$ are covered as "public morals" according to Art. XX (a). Panels and the Appellate Body have interpreted this term flexibly allowing also for some scope for contracting states to define and apply it. ${ }^{143}$ However, the grounds of socio-economic impact and agricultural policy are hard to subsume. Insofar as they are interrelated with environmental concerns (such as when benefits are weighed against risks, or when agricultural ecosystems shall be protected) they may pass as grounds under Art. XX (b) GATT. For the rest (such as coexistence costs and social and regional concerns of agriculture paysanne) Art. XX GATT does not seem to provide a justification. This warns against extending the scope of Art. III.4 GATT to non-discriminatory measures.

In a more theoretical perspective the logical gap observed in relation to the SPS Agreement reappears in relation to the GATT: Widening the scope of application causes inconsistencies with the narrow reading of grounds for trade restrictions. Either the scope must be kept narrow or the justifying grounds must be extended. Or, in methodological terms: if teleological interpretation is employed in the widening of the scope the same must be done to extend the realm of legitimate restrictions, and vice versa. ${ }^{144}$

Considering the underdevelopment of the relevant doctrines my conclusion is that cultivation restrictions treating foreign and domestic GM products equally do not violate the principle of national treatment under Art. III.4 GATT. Grounds under Art. XX GATT need not be invoked.

\section{Findings}

The opt-out concept introduced by Directive (EU) 2015/412 radicalizes the approach of the coexistence between GM, conventional and organic plant culti- 
vation. It aims at resolving the Member States' conflict about gene technology by facilitating the pluralisation of cultivation regulations. In its application, the directive must be granted effet utile. The concept is at the same time an example for a reorientation of European and possibly global principles of free trade. Whereas trade restrictions on grounds of health and environmental protection could thus far only be justified on a strict scientific basis, now a variety of risk perceptions and cultures of response are accepted.

Two types of grounds can be distinguished that go beyond those environmental risks which can be proven by science in a narrow sense ${ }^{145}$ :

- Grounds of general environmental policy: They must not conflict with scientific statements and assessments of the EIA, but may be based on independent fundamental evaluations about uncertainty, indirect and long-term effects, systemic effects and the holistic protection of nature. One needs therefore to distinguish between the scientific study and appreciation of risk, which are the subject of the so-called risk assessment, and the weighing of risk, which (in addition to the choice of instruments) is the subject of risk management.

- Trans-environmental grounds including

- socio-economic grounds: They can aim at avoiding the economic costs associated with small-scale coexistence rules, carry out a weighing of residual risks with the benefits of GMOs and/ or accommodate consumer preferences.

- grounds of agricultural policy: They can aim at protecting agricultural habitats; more generally, they can be directed against the industrialization of agriculture and for promoting conventional agriculture paysanne or organic agriculture.

- ethical grounds: they can rely on the wisdom of the trial and error processes of evolution, protect the inherent characteristics of all living creatures or aim at expressing reverence for the Creation.

The measures based on those grounds may be designed with a local, regional or national scope and consist of mere restrictions or the complete ban of the cultivation of particular GM plants. They must be proportionate. Since restrictions are not imposed by individual acts but by general norms, the test of available alternatives must not refer to the circumstances of each concerned individual but to those concerned in general. Concerning different treatment of GM and other agriculture a strict requirement of co- herent strategies cannot be assumed. Nevertheless, if for instance a cultivation ban on GMOs is meant to prevent the further industrialization of agriculture, a political concept should exist that provides for like measures concerning conventional agriculture.

Regarding the compatibility of opt-out measures with the EU principle of free movement of goods, it is submitted that the Directive establishes an exhaustive regulation that supersedes the test under Arts. 34/36 TFEU. In the alternative, the grounds for cultivation restrictions can be based on recognized public interests of the Union.

As far as the compatibility with the SPS Agreement is concerned, a thorough analysis of its scope is required. The Panel in the EC-Biotech Products case overstretches the relevant terms - risks to animals and plants from pests - in three directions, i.e. the endpoints, the factors and the causal chains. Thus measures based on general environmental policy grounds and a weighing of risks would be covered, possibly even measures that are based on trans-environmental grounds. In contrast, a more appropriate reading would confine the scope to measures aiming at the protection of concrete adverse effects.

In contrast to the wide range of scope of the SPS Agreement, the Panel takes the required risk assessment to be a narrowly science-related one. This creates a logical gap, for general environmental evaluations of risk weighing cannot be subjected to a precise inquiry into the seriousness and probability of damage. Such gap must be avoided. Either the scope of applicability must be kept narrow, or the requirement of risk assessment must be opened up to allow for a mere substantiation of risk if the measure is based on more general environmental evaluations and risk weighing. It is true that this suggestion deviates from the Panel's opinion but indications exist that a Panel or the Appellate Body would in future proceedings come to a different conclusion.

Concerning the compatibility with the TBT Agreement it is submitted that this agreement is not applicable because cultivation restrictions relate to the use of products and therefore are not technical regulations of trade.

Finally, Art. III.4 of the GATT is not breached because cultivation restrictions would not treat foreign

145 It should be noted that the two types do not have sharp contours but may overlap depending on specification. 
products less favourable than internal products. In the alternative, if a less favourable treatment were assumed to cover de facto differentials due to different market shares, the legitimate grounds for restric- tions under Art. XX GATT would have to be widened to include environmental policy in general as well as trans-environmental considerations short of protectionist intentions. 